\title{
The second occurence of the troglobic shrimp Macrobrachium microps Holthuis (Crustacea, Decapoda, Palaemonidae), in Samoa
}

\author{
Alexander J. Bruce * and Thomas M. Iliffe **
}

\section{SUMMARY}

A single example of Macrobrachium from an anchialine lava tube on Upolu, Samoa, is described and illustrated. The specimen is referred to M. microps Holthuis, 1978, but shows some differences that may be of specific value, which are discussed. The troglobic species of Macrobrachium are reviewed.

In the Indo-West-Pacific region the species rich genus Macrobrachium, abundant in tropical fresh waters, is represented by very few troglobic species. The first to be described, M. cavernicola (Kemp, 1924) is known only from Assam, India. M. microps was described by Holthuis in 1978, from New Ireland, Papua New Guinea, and the only other species, M. poeti Holthuis (1984), is known only from central Java, Indonesia. A further addition to this sparse and scarce record is therefore of some interest.

\section{PALAEMONIDAE}

Macrobrachium microps Holthuis, 1978

Macrobrachium microps Holthuis, 1978: 210-214, Figs. 1-2; 1986: 606.

Material examined.

1 male, stn.88-36, Ana Pe'ape'a, at Tafetafe, Upolu, Western Samoa, leg. S. Sarbu and T.M. Iliffe, 19 April 1988, by dip net, from bare rock bottom in $0-80 \mathrm{~cm}$ depths of an anchialine pool.

* Division of Natural Sciences, Northern Territory Museum, P.O. Box 4646, Darwin, Australia 0801.

** Marine Biology Department, Texas A 8 M University, P.O. Box 1675, Galveston, U.S.A. 77553. 


\section{Description.}

A small shrimp of slender, glabrous, smooth, subcylindrical body form.

Rostrum short, about 0.4 of carapace length, straight, horizontal, extending to about middle of distal segment of antennular peduncle, slightly upturned distally, about 5.0 times longer than deep, dorsal carina with 4 acute teeth, with 6 postorbital acute teeth, first tooth at about 0.45 of carapace length, first 3 teeth articulated, with short simple setae laterally, anterior teeth non-articulate, separated by rows of short plumose median setae, ventral margin feebly convex, with 4 small acute teeth, separated by medial row of short plumose setae, proximal tooth situated anteriorly to eighth dorsal tooth, proximal ventral margin with submedian rows of short plumose setae; orbit feebly developed, inferior orbital angle slightly produced, antennal spine large, acute, slightly postmarginal, with short carina, hepatic spine well developed, articulate, rigid, well below level of antennal spine, branchiostegal suture distinct, anterolateral angle of carapace bluntly obtuse.

Abdomen with sixth segment about 3.0 of carapace length, 1.2 times longer than deep, 1.4 times longer than fifth segment, posterolateral and posteroventral angles acutely produced, pleura of first three segments broadly rounded, fourth and fifth strongly acutely produced posteroventrally, ventral margins with plumose setae, sternite of first segment with acute median tooth, smaller teeth on second and third sternites. Telson about 0.5 of carapace length, 0.6 times sixth segment length, 3.0 times longer than wide, with two pairs of small dorsal spines, at 0.4 and 0.6 of telson length, posterior margin about 0.3 of anterior margin width, angularly produced, with acute median point, with two pairs of posterolateral spines, lateral spines small, short, about 0.5 of dorsal spine length, medial spine long, about 0.11 of telson length, 2.0 times dorsal spine length, far exceeding tip of telson, central posterior margin with 9 long subventral plumose setae, with few shorter simple setae dorsally.

Eye strongly reduced, with small well pigmented cornea, about 2.0 times wider than deep, 0.5 of stalk width, oblique, stalk swollen, 2.0 times wider than deep, compressed, eye reaches to about 0.4 of length of proximal segment of antennular peduncle.

Antennule with proximal segment about 1.4 times longer than central width, ventromedial margin without acute tooth, lateral 


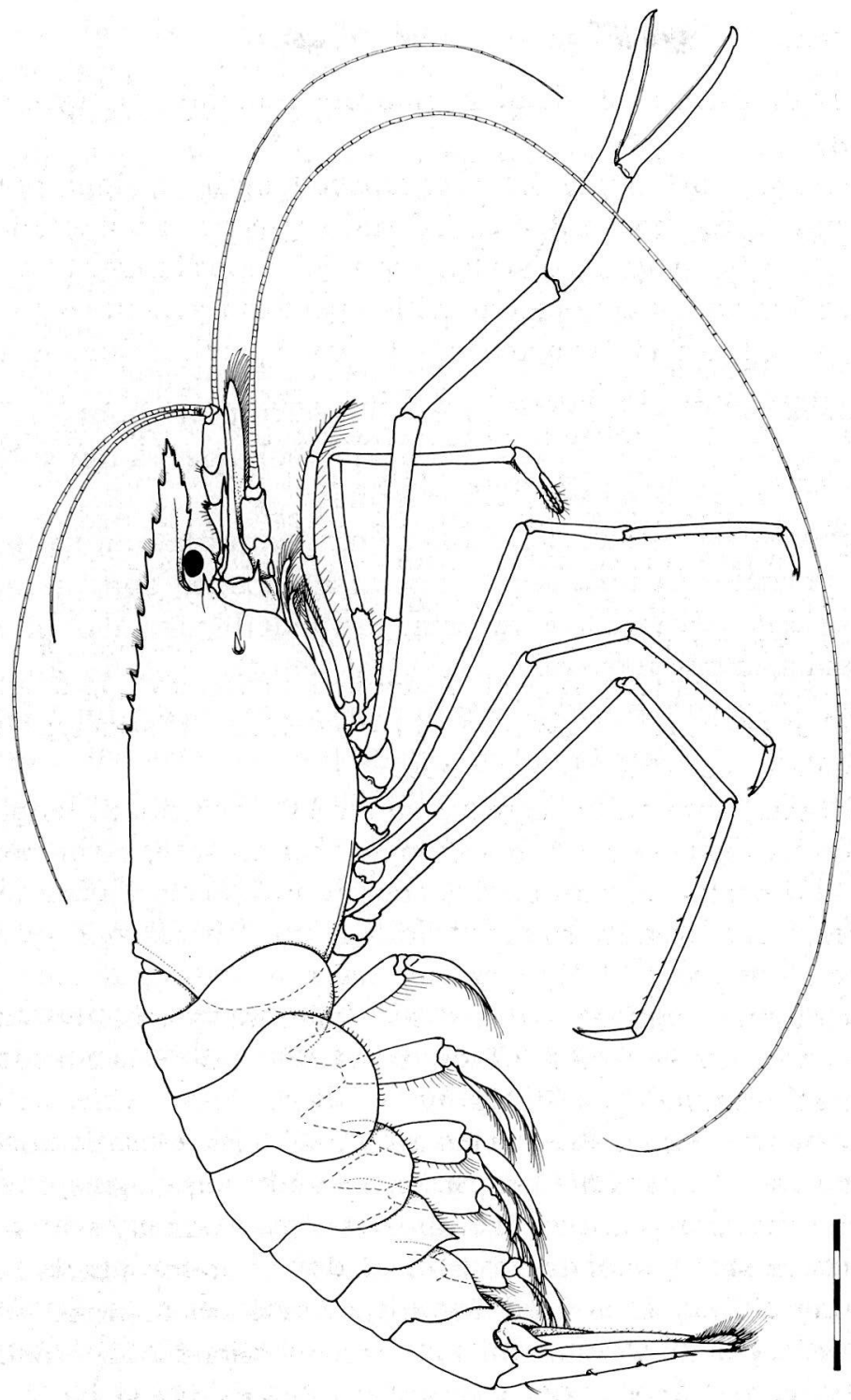

Fig. 1 - Macrobrachium microps Holthuis, male, Upolu, Samoa. Scale divisions in millimetres. 
margin sublinear, anterolateral angle strongly produced, with long slender acute distolateral tooth reaching easily to level of distal margin of intermediate segment of peduncle, anteromedial margin smoothly concave, setose, stylocerite slender, reaching to about 0.6 of proximal segment length, statocyst present, statolith feebly developed; intermediate segment about 0.5 of proximal segment length, 1.4 times longer than wide, with large oblique articulation with distal segment; distal segment about 1.3 times length of intermediate segment, 2.0 times longer than proximal width; upper flagellum biramous, 5 proximal segments fused, shorter ramus about 0.75 of carapace length, 10 times fused portion length, longer ramus subequal to shorter ramus length (?, tips missing).

Antenna with basicerite with strong slender lateral tooth, with small subacute ventrolateral carina; ischiocerite and merocerite normal; carpocerite short, extending to about distal end of proximal segment of antennular peduncle, 0.3 of scaphocerite length, about 3.0 times longer than wide, flagellum well developed, long slender, about 4 times carapace length (?, distal portion missing); scaphocerite with lamella distinctly exceeding antennular peduncle, distolateral spine slightly exceeding peduncle, lamella about 3.6 times longer than width, width maximal at 0.3 of length, lateral margin stright, with strong distolateral tooth, well exceeded by angular, bluntly rounded distal lamella.

Ophthalmic somite with small rounded bec ocellaire, with small median pigment spot. Epistomal region without special features. Labrum with anterior median carina.

Mandible (right) with corpus stout, with slender, 3-segmented palp, with numerous short simple spines and setae, segment lengths in ratio 1.6:1.0:1.8; molar process robust, truncate distally, with 4 blunt peripheral teeth, 1 trullate tooth posteriorly, incisor process short, broad, with 3 stout acute teeth distally, central tooth slightly smaller than outer teeth. Maxillula with palp deeply bilobed, upper lobe elongate, slender, with numerous short simple setae, lower lobe short, tapering, with single simple distodorsal seta, non-setose distoventral tubercle; upper lacinia slender, tapering, distally truncate, with about 12-13 simple spines, with numerous finely serrulate spiniform setae distally and ventrally, sparse simple setae along dorsal margin; lower lacinia tapering, distally subacute, with numerous finely serrate setae. Maxilla with tapering, distally acute palp with single short 


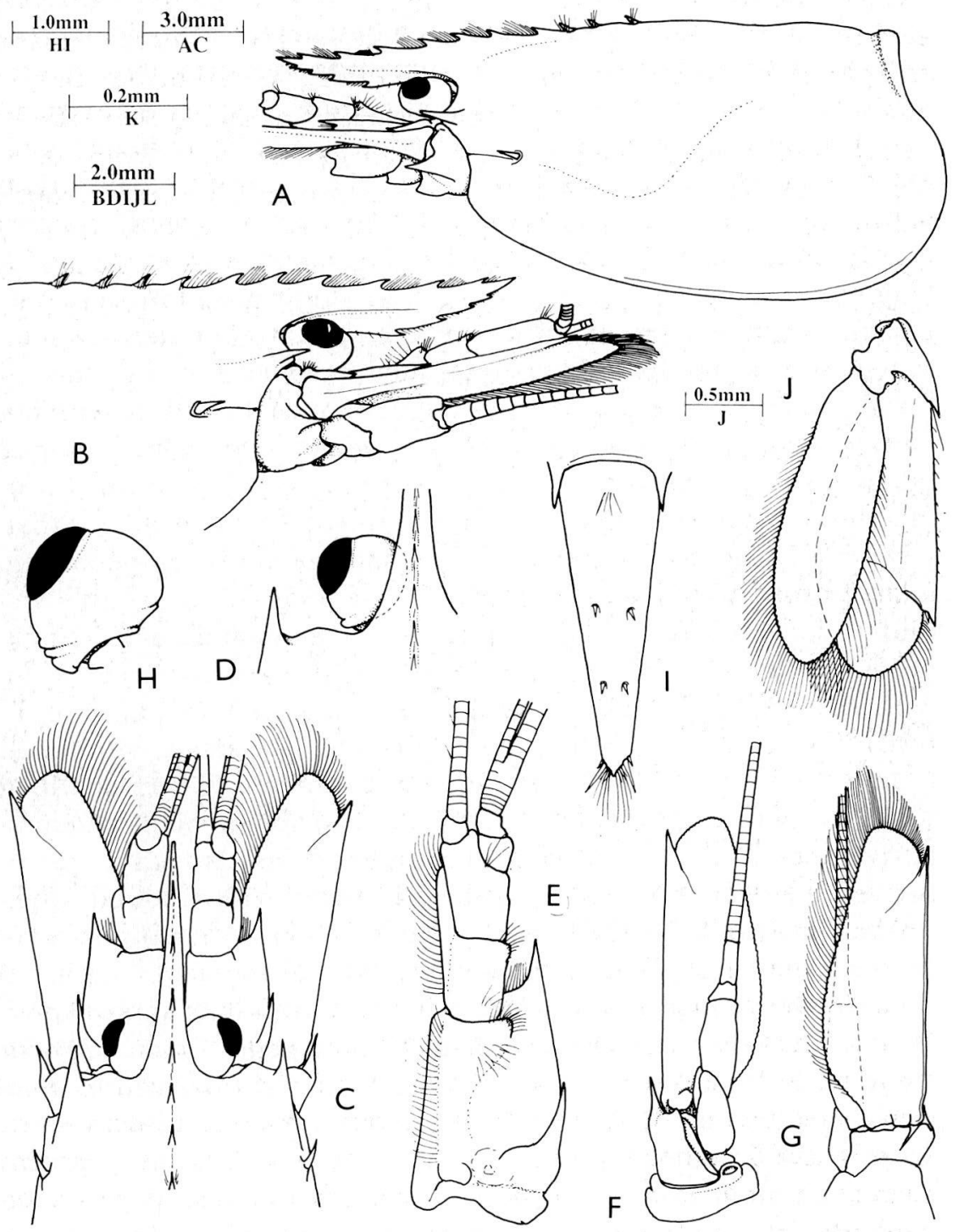

Fig. 2 - Macrobrachium microps Holthuis. A, carapace and antennal peduncles. $\mathrm{B}$, anterior carapace, rostrum and antennal peduncles, lateral. C, same, dorsal. D, left orbital region, dorsal. E, antennular peduncle. F, antenna, ventral. G, same, dorsal. $\mathrm{H}$, eye, ventral. I, telson. J, uropod. 
simple preterminal seta, with several short plumose setae proximolaterally, basal endite with 2 elongate lobes, upper lobe slightly longer and broader than lower, with numerous short simple setae distally, with similar setae along dorsal margin of upper and ventral margin of lower lobe, coxal endite obsolete, medial margin feebly bilobed; scaphognathite well developed, about 3.0 times longer than wide, posterior lobe large, anterior lobe narrow, medial margin deeply emarginate. First marilliped with elongate, slender palp with long preterminal seta, several short setae on proximal medial margin, basal endite large, broadly rounded, woth straight densely setose medial margin, distinctly demarkated from coxal endite, medial margin thickened, setose, exopod well developed, flagellum with numerous long plumose setae distally, caridean lobe normal, epipod bilobed, distal lobe larger than proximal. Second maxilliped normal, with endopod normal, dactylar segment 2.6 times longer than wide, with numerous robust simple spines medially, propodal segment broadly rounded distomedially, with long slender simple spiniform setae distomedially, carpus with distomedial angle acutely produced, basis feebly excavate medially, exopod well developed, with numerous plumose setae distally, coxa with medial margin broadly rounded with numerous slender simple setae, with small rounded epipod laterally, with small podobranch. Third maxillped with endopod slender, reaching anteriorly to about end of antennular peduncle, ischiomeral segment completely fused to basis, combined segment about 5.7 times longer than distal width, bowed, slightly expanded and flattened distally, medial and lateral margins setose, penultimate segment about 0.6 of proximal segment length, 5.0 times longer than proximal width, with numerous long simple spiniform setae, terminal segment about 0.75 of penultimate segment length, slender, about 6.5 times longer than proximal width, tapering to acute point distally, with numerous simple spiniform setae, exopod well developed, reaching to about 0.75 of proximal segment length, with numerous plumose setae distally, coxa feebly produced medially, sparsely setose, with small oval lateral plate, larger lower and smaller upper arthrobranchs laterally.

Thoracic sternites 1-3 broad, with low transverse ridges, 4 unarmed, without median process, 5-8 narrow, unarmed.

First pereiopod very slender, exceeding carpocerite by distal merus, rostrum by 0.6 of carpus; chela with palm about 2.6 times longer than central depth, subequal to length of fingers, fingers 


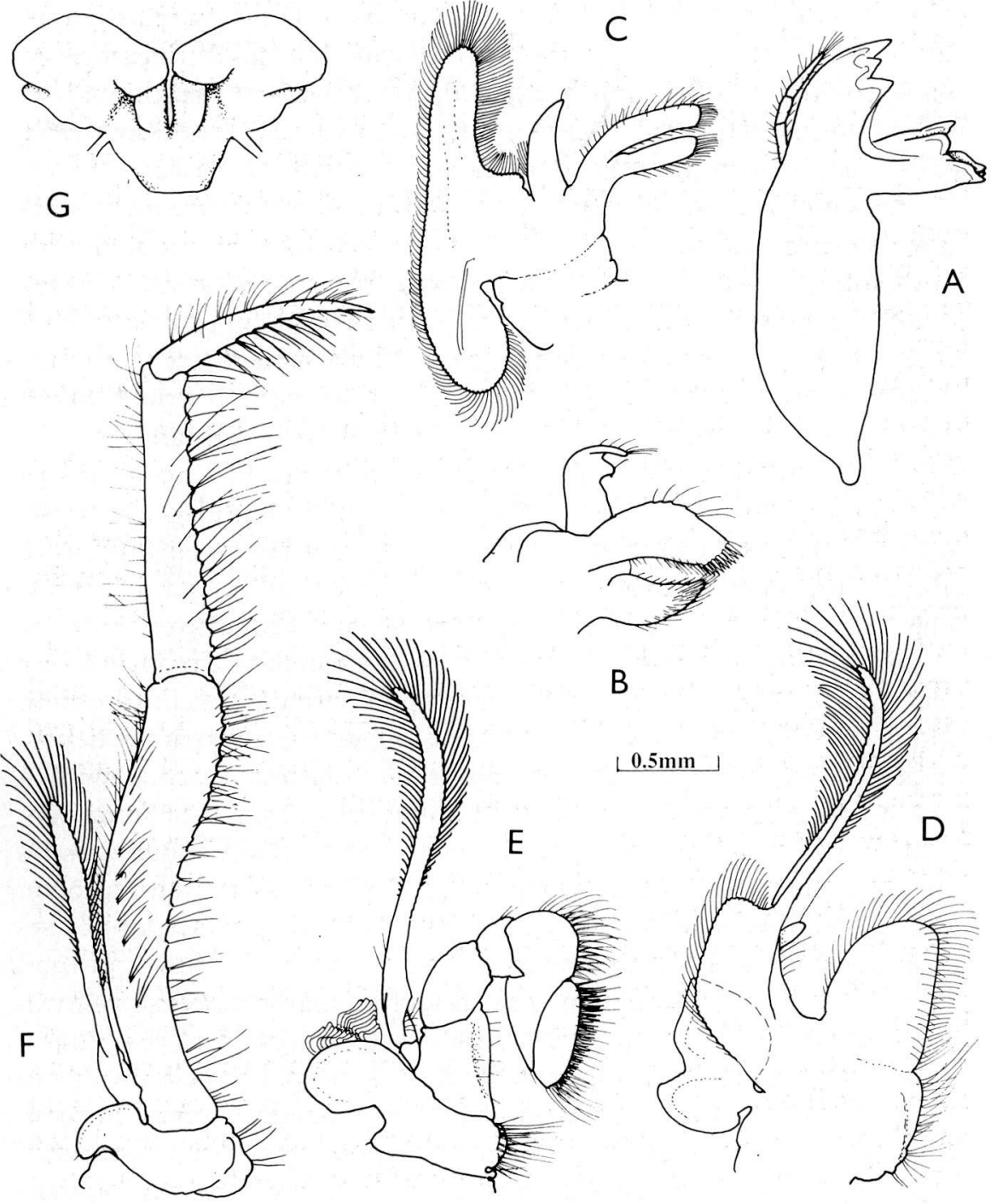

Fig. 3 - Macrobrachium microps Holthuis, right mouthparts. A, mandible. B, maxillula. C, maxilla. D, first maxilliped. E, second maxilliped. F, third maxilliped. 
slender, dactyl 7.0 times longer than proximal depth, with entire cutting edges and small acute hooked tips; carpus about 1.9 times chela length, about 10 times longer than distal width, slightly tapering proximally; merus about 0.85 of carpus length, 8 times longer than proximal width, slightly expanded and setose proximomedially, ischium subequal to chela length, 0.6 of meral length, medially setose; basis normal; coxa with small distoventral lobe.

Second pereiopods subequal, similar, slender, smooth, exceeding rostrum by carpus, chela and distal sixth of merus; chela with palm subcylindrical, slightly swollen centrally, smooth ?, 2.9 times longer than deep, fingers slender, 1,45 times palm length, dactyl 8.5 times longer than proximal depth, with 3-4 very small low teeth proximally, rest of cutting edge sharp, entire, with small acute hooked tip, fixed finger similar, with single small tooth proximally; carpus about 1.25 times palm length, subequal to length of fingers, 6.0 times longer than distal width, slightly expanded distally, unarmed; merus 1.1 times carpus length, 11 times longer than central width, slightly expanded distally, unarmed; ischium about 0.6 of meral length, unarmed; basis and coxa without special features.

Ambulatory pereiopods slender, third exceeding carpocerite by dactyl, propod and carpus; third pereiopod with dactyl compressed, about 0.3 of propod length, 5.5 times longer than proximal depth, feebly curved, with acute tip, unguis not distinct, corpus with 4 groups of short spiniform setae dorsolaterally, 2 pairs of setae ventrally and distoventral group of longer setae; propod about 0.44 carapace length, 16.5 times longer than central width, subuniform, with 10 small ventral spines, 2 small distoventral spines, sparsely setose; carpus about 0.65 of propod length; merus 1.2 times propod length, 9.5 times longer than central width, sparsely setose ventrally, devoid of spinules, unarmed; ischium about 0.4 of merus length; basis and coxa without special features; fourth pereiopod similar to third; fifth pereiopod with propod 1.5 times length of third propod, with 10 small ventral spines, smaller spines on dorsal margin, 5 transverse rows of setae distoventrally, without distoventral spines.

First pleopod with basipodite 2.2 times longer than broad; endopod about 0.6 of basipodite length, 3.5 times longer than proximal width, distinctly curved medially, distomedial third and distolateral two third of margin with short finely plumose setae, proximal medial margin with numerous short slender spiniform setae, 5 longer coarsely plumose setae, exopod 2.0 times endopod length. Second 


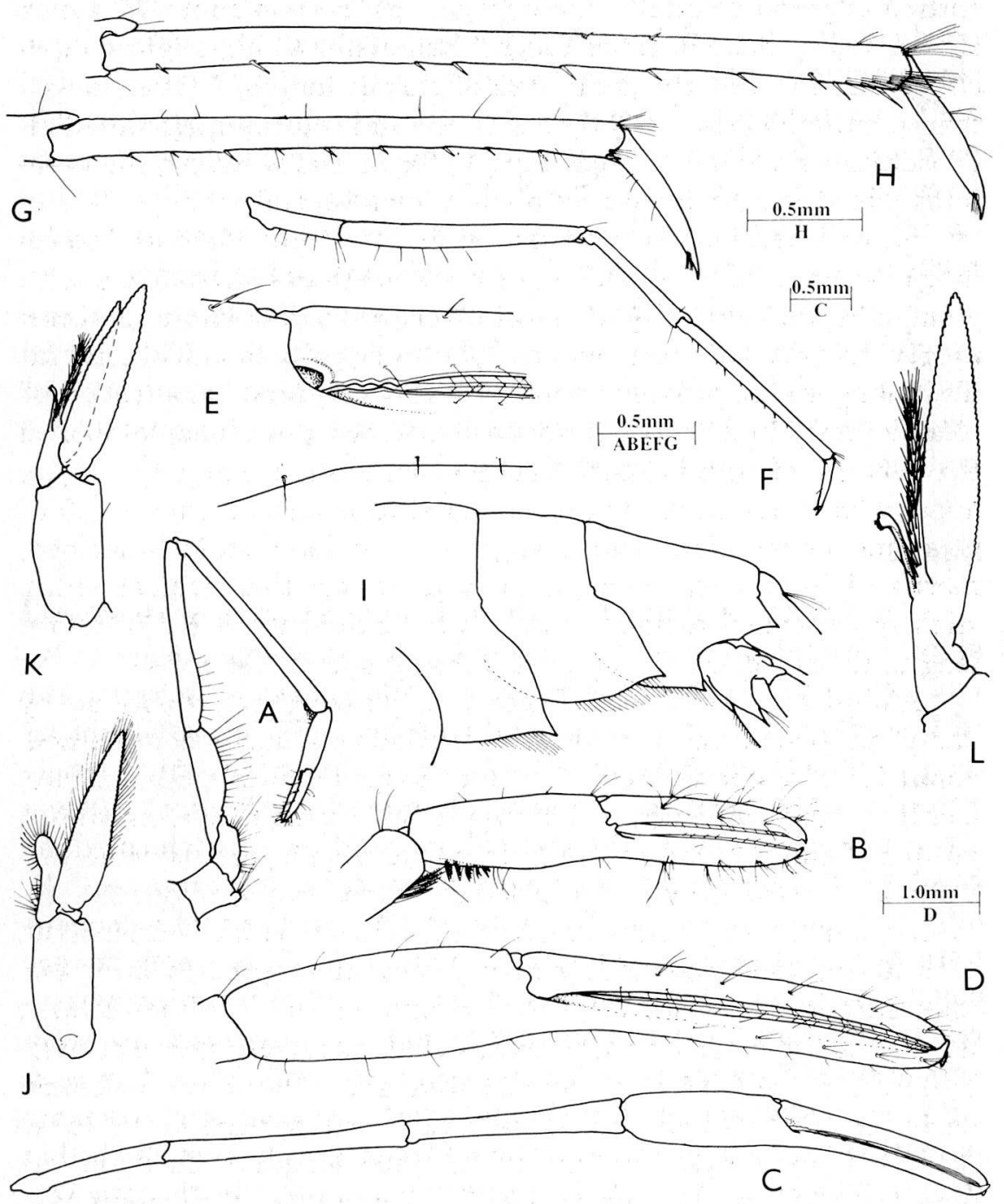

Fig. 4 - Macrobrachium microps Holthuis. A, first pereiopod. B, same, chela. C, second pereiopod, right. D, same, chela. E, same, dactylo-propodal articulation. F, third pereiopod. G, same, dactyl and propod. H, fifth pereiopod. I, fourth to sixth abdominal segments, lateral. J, first pleopod. K, second pleopod. L, same, endopod. 
pleopod with basipodite 2.2 times longer than wide, 1.1 times first pleopod basipodite length; endopod 1.3 times basipodite length, appendices at 0.3 of medial margin length, appendix masculina long, slender, subcylindrical, about 13 times longer than central width, feebly tapering distally, reaching to about 0.75 of endopod length, with about 15 transverse rows of slender simple spiniform setae ventrally, appendix interna about 0.5 of appendix masculina length, reaching to 0.5 of endopod length, with few distal cincinnuli; endopod 6.5 times longer than wide, 1.4 time basipodite length.

Uropod with protopodite with strong acute distolateral process; exopod subequal to telson length, 2.5 times longer than wide, lateral margin straight, with acute distolateral tooth at about 0.75 of length, with small mobile spine medially; endopod subequal to exopod length, 3.3 times longer than wide.

\section{Habitat}

Ana Pe'ape'a at Tafetafe is an anchialine lava tube cave located about $1 \mathrm{~km}$ inland from the coast of Upolu at Tafetafe village. In Polynesian, "ana» is the word for cave, while «pe'ape'a» refers to the cave swallow. This cave has a total length of $1,572 \mathrm{~m}$, of which 102 $\mathrm{m}$ is an underwater passage (Fig. 6). Ana Pe'ape'a has only a single entrance with passages trending in opposite directions. Downstream (in relation to the direction of the lava flow which formed the cave), a $5 \mathrm{~m}$ wide by $2 \mathrm{~m}$ high gallery reaches a subterranean lake after a distance of $200 \mathrm{~m}$. The water in the lake gradually deepens until the passage becomes totally submerged. This water is very clear, with underwater visibility in excess of $30 \mathrm{~m}$. Salinity (measured with a calibrated refractometer) and water temperature were $1 \mathrm{ppt}$ and $23^{\circ} \mathrm{C}$ respectively. The bottom consisted of bare lava rock with only a small amount of silt and a few small pieces of wood apparently washed into the cave. The underwater tube was blocked at its terminus by a large boulder cemented into place by the lava. Peering through a small hole, it was possible to see the passage continuing south toward the coast past the obstruction. Several small, reddish to clear coloured atyid shrimps were also collected from the cave.

Upolu is a volcanic island of Pliocene age located in the central South Pacific at about $14^{\circ} \mathrm{S}$ and $172^{\circ} \mathrm{W}$. Pleistocene to Holocene age eruptions along the central spine of the island have produced lava flows that spread out as fans to reach the coast. 


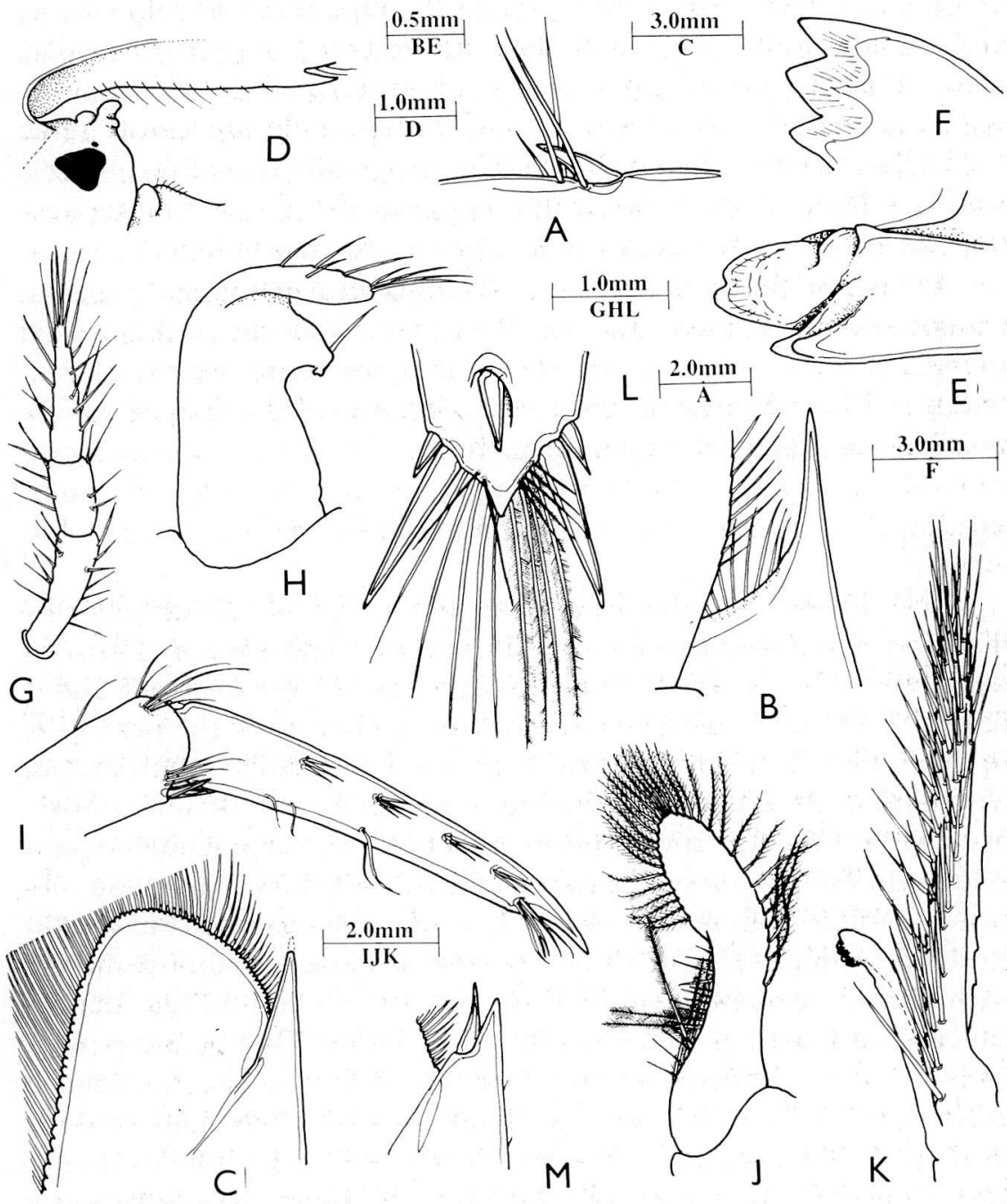

Fig. 5 - Macrobrachium microps Holthuis. A, posterior rostral spine. B, proximal segment of antennular peduncle. C, scaphocerite. D, ophthalmic somite. E, mandible, molar process. F, same, incisor process. G, same, palp. H, maxillula, palp. I, third pereiopod, dactyl. J, first pleopod, endopod. K, second pleopod, endopod, appendices. L, telson, posterior spines, left dorsal spine superimposed. M, exopod of uropod, postero-lateral angle. 


\section{Systematic remarks}

Assessment of the correct systematic position of the specimen under consideration presents some difficulties. Like the original material of Macrobrachium microps, only a single male specimen is available. While it is evident that the holotype of M. microps is a fully developed male, the developmental status of the Samoan specimen is uncertain, making a full comparison difficult. The separation Macrobrachium males when only not fully developed males are available is notoriously uncertain. The Samoan specimen presents a number of differences from the New Ireland specimen that might suggest that separate taxa are involved, a possibility that is increased by the considerable geographic separation of the sites of collection. Although many anchialine shrimps, of marine origin and presumably with planktonic larval stages, are of very wide geographical distribution, this is much less marked in freshwater troglobic forms.

The present specimen has a rostrum that is slightly shorter than the antennular peduncle, and has only 10 dorsal and 4 ventral teeth, whereas the $M$. microps holotype has 11 dorsal teeth and 3 ventral teeth, with the rostrum reaching to the end of the peduncle. In the Samoan specimen the first three dorsal teeth are articulated, with simple setae lateral to the tooth, with the more distal teeth separated by a median row of plumose setae. This arrangement is not evident in the holotype. The antennal spine appears longer and more acute in the Samoan specimen. The Samoan specimen has the distolateral angle of the proximal segment of the antennular peduncle with a more strongly acute tooth, with the medial margin deeply concave, rather than convex as in the holotype. The second pereiopods in the two specimens are markedly different, but the slender gracile from of the Samoan specimen could be only undeveloped from of the New Ireland specimen, or of something quite different. The ambulatory pereiopods in the Samoan specimen are distinctly more slender than in the New Ireland specimen, with the third propod about 16 times longer than the central width, as opposed to 10.75 times and with propod 3.5 times the dactyl length as opposed to 2.75 times. The ventral surface of the merus is without spinules, which are present in the holotype.

Holthuis (1986) listed only 6 stygiobiont species of Macrobrachium, together with an additional 12 stygiophile and stygoxene 


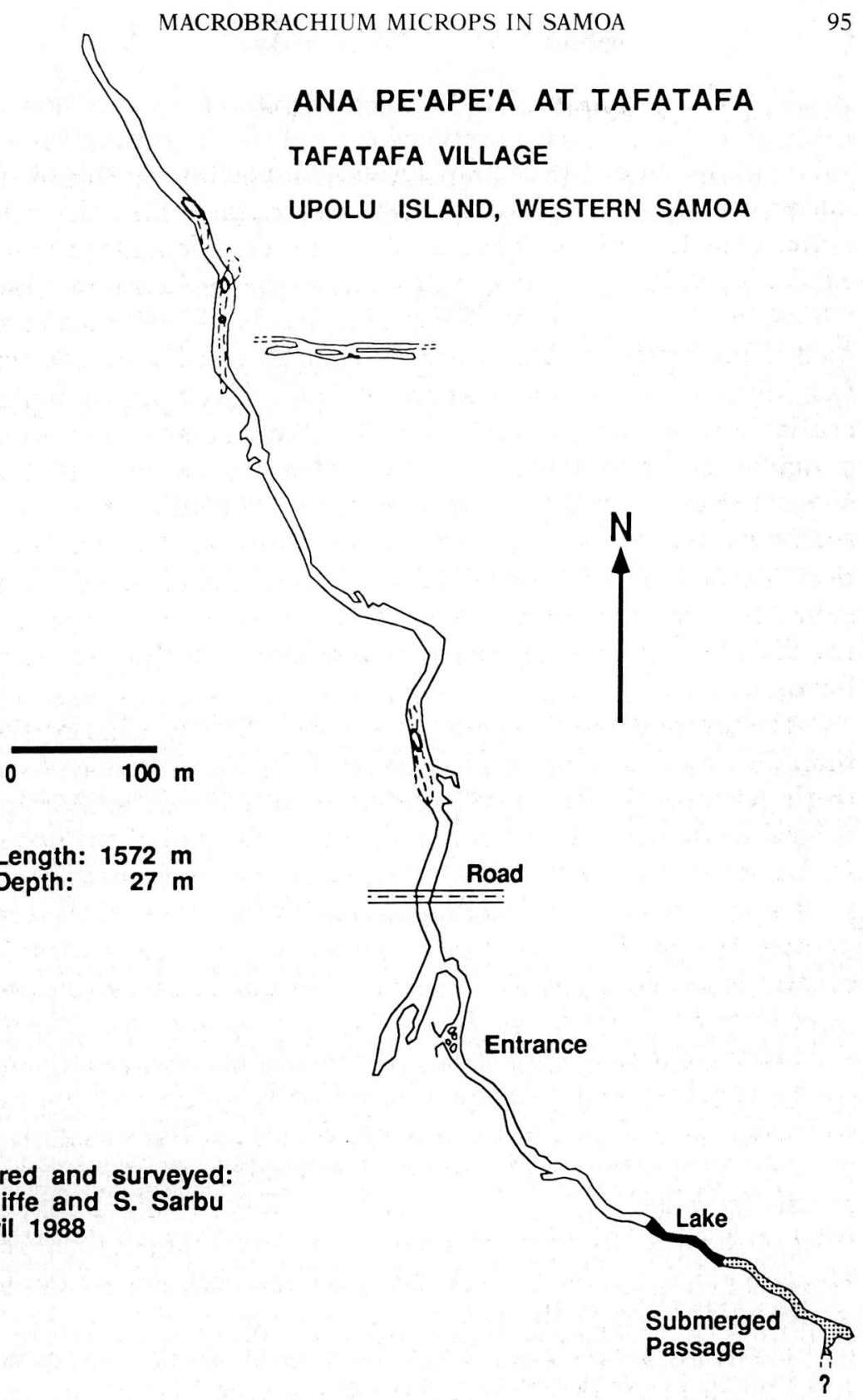

Fig. 6 - Map of Ana Pe'ape'a at Tafetafe, Upolu, Western Samoa. 
species. Sinces that date no further stygiobiont species have been described. Three species are known from the Indo-West Pacific region and three from the Central American-Caribbean region. There results are summarized on the following table.

The Stygiobiont Species of Macrobrachium Bate, 1868 (after Holthuis, 1986)

\author{
M. cavernicola (Kemp, 1924) \\ M. villalobosi Hobbs, 1973 \\ M. lucifugum Holthuis, 1974 \\ M. acherontium Holthuis, 1977 \\ M. microps Holthuis, 1978 \\ M. poeti Holthuis, 1984
}

\author{
India \\ Mexico \\ Curacao, Bonaire, Santo Domingo, \\ Jamaica, Cuba \\ Mexico \\ New Ireland \\ Java
}

\section{ACKNOWLEDGEMENTS}

Biospeleological investigations in Western Samoa were part of a year long expedition studying the fauna of anchialine caves in the South Pacific. This research was supported by grants from the National Science Foundation (BSR-8700079) and the National Geographic Society (3412-86). Mr Dan Sua, of the Western Samoa Department of Fisheries, provided considerable logistical assistance. Serban Sarbu and Yolanda Iliffe aided with the cave collections.

\section{REFERENCES}

HOBBS, H.H. 1973. Two new troglobitic shrimps (Decapoda: Alpheidae and Palaemonidae) from Oaxaca, Mexico. Association of Mexican Cave Studies, Bulletin 5: 73-80, figs. 1-3.

HOLTHUIS, L.B. 1974. Subterranean Crustacea Decapoda Macrura Collected by Mr. L. Botosaneanu during the 1973 Cuban-Rumanian Biospeleological Expedition to Cuba. International Journal of Speleology, 6: 231-242, figs. 1-3.

HOLTHUIS, L.B. 1977. Cave shrimps (Crustacea, Decapoda, Natantia) from Mexico. - Subterranean fauna of Mexico. Part III. Further results of the Italian zoological missions to Mexico, sponsored by the National Academy of Lincei (1973 and 1975). Problemi attuali di Scienze e di Cultura, Accademia nazionale dei Lincei, 171 (3): 173-195, figs. 1-8.

HOLTHUIS, L.B. 1978. Cavernicolous shrimps (Crustacea Decapoda, Natantia) from New Ireland and the Philippines. - Zoological results of the British Speleological Expedition to Papua New Guinea, 1975. Part. 7. Zooloogische Mededelingen, 53 (19): 209-224, figs. 1-6.

HOLTHUIS, L.B. 1984. Freshwater prawns (Crustacea Decapoda: Natantia) from subterranean waters of the Gunung Sewu area, cental Java, Indonesia. Zoologische Mededelingen, Leiden, 58 (9): 141-149, fig. 1.

HOLTHUIS, L.B. 1986. Decapoda. In: Botosaneanu, L. (ed.), Stygofauna Mundi, Brill, Leiden, pp. 589-615, figs. 1-18.

KEMP, S. 1924. Crustacea Decapoda of the Siju Cave, Garo Hills, Assam. Records of the Indian Museum, 26: 41-48, pl. 3. 